\title{
Koronavirusna bolezen (covid-19) pri otrocih
}

\section{Coronavirus disease (COVID-19) in children}

Tina Plankar Srovin, Tanja Avramoska, Natalija Bahovec, Simona Bizjak Vojinovič, Aida Granda, Liza Lea Lah, Tatjana Mrvič, Veronika Osterman, Petra Prunk, Mojca Rožič, Urša Šivic, Katarina Vincek, Breda Zakotnik

\section{Izvleček}

Pri otrocih koronavirusi običajno povzročajo blage okužbe dihal. V zadnjih dveh desetletjih so se iz živalskih rezervoarjev na človeka razširile tri vrste koronavirusov, ki so pri ljudeh povzročile resne bolezni s pomembno stopnjo umrljivosti. Decembra 2019 je na Kitajskem izbruhnila nova koronavirusna bolezen covid-19, ki jo povzroča virus SARS-CoV-2, in se je v treh mesecih razširila po vsem svetu.

Glavna načina prenosa sta kapljični in kontaktni. Povprečna inkubacijska doba je 4-6 dni.

Bolezen se pri otrocih večinoma kaže z nespecifičnimi simptomi in znaki akutne virusne okužbe dihal, v manjšem deležu pa so pridruženi tudi gastrointestinalni simptomi. Najpogostejša klinična znaka sta vročina in kašelj. Bolezen je samoomejujoča in jo večina otrok brez posledic preboli v 1-2 tednih po nastopu bolezni. Pri delu otrok bolezen poteka brez simptomov, medtem ko do $6 \%$ otrok s potrjeno okužbo s SARS-CoV-2 prizadene težka in kritična oblika bolezni. Konec aprila so se v povezavi s prebolelo boleznijo covid-19 začeli pojavljati opisi otrok s prekrivajočo se klinično sliko Kawasakijeve bolezni in sindroma toksičnega šoka. Natančna patogeneza še ni znana, morda gre za superantigensko povzročeno aktivacijo imunskega sistema. Specifičnega zdravljenja za covid-19 trenutno nimamo. Pripravljajo cepiva, ki naj ne bi pripomogla le k obvladovanju oz. omejitvi trenutne epidemije, ampak tudi k preprečevanju podobne epidemije v prihodnje.

Ključne besede: covid-19, otroci, pandemija, zdravljenje, cepiva, preventivni ukrepi.

\begin{abstract}
Coronaviruses generally cause a mild respiratory tract infection. In the last two decades, three types of coronavirus have spread from animal reservoirs to humans causing severe diseases with a high mortality rate. The outbreak of new coronavirus disease - COVID-19, which is caused by SARS-CoV-2, began in China and spread worldwide in less than 3 months.

Main routes of viral transmission are via droplets and contact with soiled surfaces and fomites. The incubation period is estimated to be $4-6$ days.

Most children have mild disease with nonspecific symptoms and signs of upper respiratory tract infection, in a smaller proportion, gastrointestinal symptoms are present. The most common encountered symptoms are fever and cough. The disease course is mostly self-limiting with uneventful recovery in 1-2 weeks. Severe disease is rare (up to $6 \%$ ). From late April we are witnessing emerging reports of children with a severe inflammatory disease resembling Kawasaki disease and toxic shock syndrome. Pathogenesis of this syndrome is not yet well understood; the severe inflammatory response might be caused by activation of the immune system by superantigen induced by the virus.

Currently, there is no specific treatment for COVID-19. A few vaccines are in the pipeline, which might help not only in controlling and limiting the current epidemic but eventually preventing similar epidemics in the future.
\end{abstract}

Key words: COVID-19, children, pandemic, therapy, vaccines, preventive measures. 


\section{Uvod}

Decembra 2019 so v kitajskem mestu Wuhan zaznali izbruh nove infekcijske bolezni, ki se je hitro širila med ljudmi in povzročila prezasedenost bolniških postelj. Poimenovali so jo koronavirusna bolezen 2019 oz. covid-19 (angl. coronavirus disease 2019; COVID-19). Bolezen povzroča novi koronavirus SARS-CoV-2 (1), ki se je $v$ treh mesecih razširil po vsem svetu. Tako je 11. marca Svetovna zdravstvena organizacija (SZO) razglasila pandemijo covid-19, ki je do konca maja terjala že več kot 370.000 smrtnih žrtev $(2,3)$.

Za covid-19 zbolevajo odrasli in otroci. Pri otrocih je bolezen redkejša in poteka v blažji obliki (4). V preglednem prispevku predstavljamo covid-19 pri otrocih.

\section{Koronavirusi}

Koronavirusi so skupina RNK virusov. Ime so dobili po svojem izgledu pod elektronskim mikroskopom, saj je njihova značilna koničasta oblika glikoproteinov na ovojnici videti kot krona (lat. corona) (5). Sodijo v družino Coronaviridae (koronavirusi, CoV) s poddružino Orthocoronavirinae in jih razvrščamo v štiri rodove:

- koronavirusi alfa (alphaCoV) in koronavirusi beta (betaCoV), katerih genski vir so najverjetneje netopirji in glodalci;

- koronavirusi delta (deltaCoV) in koronavirusi gama (gammaCoV), katerih genski vir so ptiči in ribe (6).

Koronavirusna ovojnica je sestavljena iz lipidnega dvosloja, v katerem so zasidrani strukturni proteini membrane $(M)$ in ovojnice (E) ter koničasti glikoproteini (S) (Slika 1). Podvrste koronavirusov imajo tudi krajši površinski protein v obliki bodic, ki ga imenujemo hemaglutinin esteraza (HE). Koničasti glikoproteini (S) na površini koronavirusov posredujejo vezavo $\mathrm{z}$ receptorji in membransko fuzijo med virusom in gostiteljevo celico, proteina $\mathrm{E}$ in $\mathrm{M}$ pa

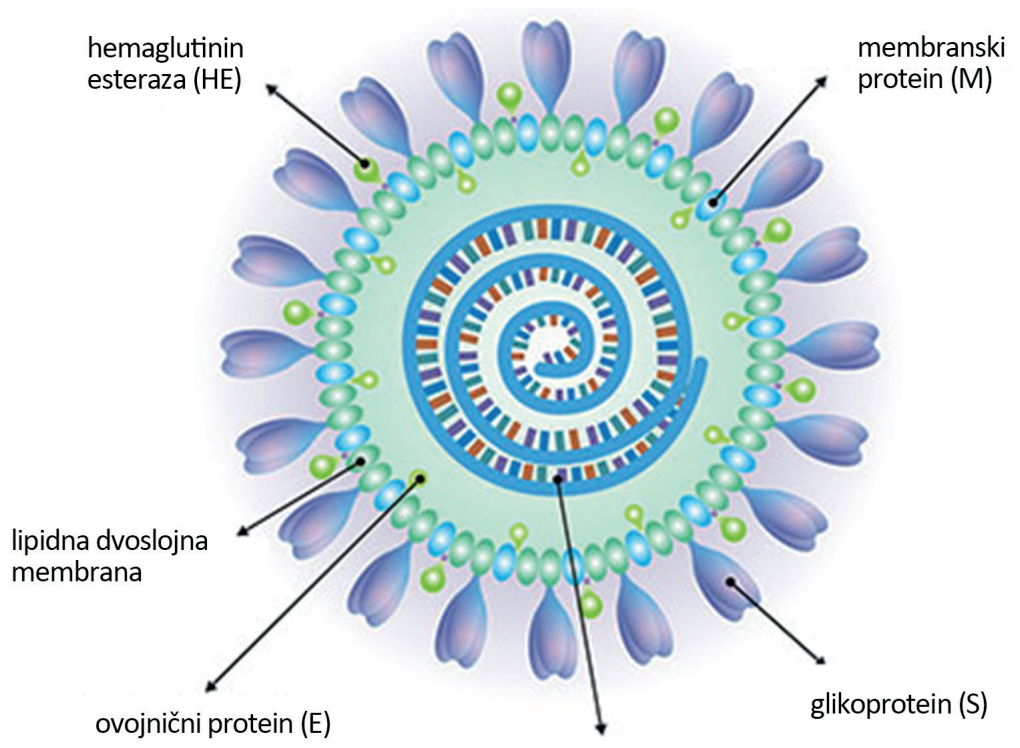

$\mathrm{RNA}+$ nukleokapsidni protein (N)

SLIKA 1: ZGRADBA VIRUSA SARS-COV-2.

FIGURE 1: SARS-COV-2 STRUCTURE.

sta pomembna pri oblikovanju virusne ovojnice in ohranjanju njene strukturne oblike. Znotraj ovojnice je nukleokapsida. Tvori jo več kopij nukleokapsidnega proteina (N), ki je vezan na enovijačno RNK. Lipidna dvoslojna ovojnica, membranski proteini in nukleokapsida varujejo virus zunaj gostiteljeve celice (5).

Koronavirusi so velika družina virusov, ki običajno povzročajo blage do zmerne bolezni zgornjih dihal (npr. navadni prehlad), prebavil, jeter in živčevja. Obstaja na stotine koronavirusov, izmed katerih večina kroži med živalmi (npr. prašiči, kamelami, netopirji in mačkami). Poznamo tudi šest sevov koronavirusov, ki povzročajo bolezen pri ljudeh (t. i. humani koronavirusi, $\mathrm{HCOV}$ ), štirje od njih nenehno krožijo v človeški populaciji. Ti virusi so HCoV-OC43, HCoV-HKU1, HCoV-229E in HCoV-NL63 (7), ki povzročajo približno 5-15\% vseh prehladnih bolezni pri človeku, medtem ko pri osebah z oslabljenim imunskim sistemom in pri starejših lahko povzročijo tudi okužbe spodnjih dihal. Približno $2 \%$ prebivalstva so zdravi prenašalci HCoV (8). V prospektivni raziskavi, ki so jo o vlogi $\mathrm{HCoV}$ pri otrocih, hospitaliziranih zaradi akutnega bronhiolitisa, akutnega gastroenteritisa ali vročinskih krčev v Ljubljani opravili Jevšnikova s sodelavci, so okužbo s HCoV dokazali pri 8,1 \% hospitaliziranih, medtem ko so v kontrolni skupini prisotnost $\mathrm{HCoV}$ dokazali v $1,9 \%$. Dokazali so okužbe $z$ vsemi štirimi sevi HCoV (9).

V zadnjih dveh desetletjih so se iz živalskih rezervoarjev pojavile tri nove vrste koronavirusov, ki so pri ljudeh povzročile resno in razširjeno obliko bolezni z visoko stopnjo umrljivosti. Vse tri vrste uvrščamo med koronaviruse beta.

- Koronavirus SARS (SARS-CoV), ki povroča t. i. sindrom akutnega oteženega dihanja (angl. severe acute respiratory syndrome, SARS), se je pojavil novembra 2002 na Kitajskem in izginil do leta 2004. Zbolelo je več kot 8000 ljudi, od katerih je približno $10 \%$ celo umrlo (10).

- Koronavirus MERS (MERS-CoV), ki povzroča t. i. bližnjevzhodni respi- 
ratorni sindrom (angl. Middle East Respiratory Syndrome, MERS), se je pojavil septembra 2012 v Savdski Arabiji in še naprej povzroča sporadične in lokalizirane izbruhe. Do novembra 2019 so po svetu zabeležili skoraj 2500 primerov z visoko smrtnostjo (34\%) (11).

- Novi koronavirus (SARS-CoV-2), ki povzroča covid-19, se je decembra 2019 pojavil na Kitajskem. Virus so odkrili 7. januarja 2020 in ga sprva poimenovali 2019-nCoV. Do konca maja 2020 je bilo zabeleženih več kot 6 milijonov okužb po vsem svetu z ocenjeno smrtnostjo 1-7 \% $(1,12)$.

Chan s sodelavci je dokazal, da ima genom SARS-CoV-2, izoliran iz bolnika z atipično pljučnico po obisku Wuhana, 89-odstotno nukleotidno skladnost z netopirjim koronavirusom SARS-CoVZXC21 in 82-odstotno nukleotidno skladnost s človeškim SARS-CoV (13). Na podlagi trenutnih raziskav se zdi, da morda SARS-CoV-2 sprva gostijo netopirji in ga na človeka prenesejo preko luskavca ali drugih divjih živali, ki jih prodajajo na trgu morske hrane v Huananu. Ker pa bi mutacija v prvotnem sevu lahko neposredno sprožila virulentnost do ljudi, tudi ni gotovo, da ta gostitelj sploh obstaja (14).

\section{Epidemiologija}

Covid-19 je precej kužna bolezen z bazičnim reprodukcijskim številom $\left(R_{0}\right)$ 2-4, ki je po oceni nekaterih matematičnih modelov tudi višji $(3,8-8,9)(12$, 15). R0 je matematični izraz, ki nam pove, kako nalezljiva je določena okužba oz. na koliko ljudi lahko ena okužena oseba prenese infekcijski agens. Med epidemijo se lahko spreminja, odvisno od števila imunsko naivnih oseb ter sprejetih ukrepov za obvladovanje in preprečevanje prenosa okužbe v okolju. Za primerjavo - R0 za ošpice je 12-18, za gripo pa 1-2 (16).

Prvi primeri okužbe pri otrocih so se začeli pojavljati v zgodnji fazi epidemi- je covid-19. Največ otrok je bilo okuženih v epicentru epidemije na Kitajskem v provinci Hubei, število okuženih otrok pa se je zmanjševalo sorazmerno z oddaljenostjo od tega območja (17). V epidemiološki analizi 31 otrok s covid-19 iz šestih Kitajskih provinc so pokazali, da ima večina zbolelih otrok stik z zbolelo osebo znotraj družine; v $68 \%$ so okužbo povezali s SARS-CoV-2 pozitivnimi starši, v $90 \%$ pa z manjšimi izbruhi znotraj razširjenih družin (18).

Po podatkih SZO je približno $70 \%$ vseh okuženih starih 40-80 let (19). Podatki iz različnih držav kažejo, da je med vsemi dokazanimi okužbami s SARS-CoV-2 1-5 \% otrok, starih 0-18 let, najmanjši delež zbolelih pa so otroci, stari 0-9 let. Prave incidence okužb pri otrocih sicer ne poznamo, saj otroci zaradi blage oblike bolezni pogosto niso testirani (4).

Glede na trenutno dosegljive podatke in izkušnje se virus SARS-CoV-2 prenaša predvsem kapljično, tj. ob stiku sluznic s kapljicami okuženega bolnika, ki nastanejo pri kihanju in kašljanju, ter kontaktno, predvsem preko onesnaženih površin. Dokazov, da se okužba prenaša aerogeno ni, izjema so le posegi, pri katerih se tvorijo aerosoli (intubacija/ekstubacija, ročno predihavanje, jemanje brisa, neinvazivno predihavanje, nekateri zobozdravniški posegi ipd.) (20). Čeprav dokaza o prenosu virusa $z$ drugimi telesnimi tekočinami oz. izločki nimamo, pa so virus dokazali virus v blatu, krvi, solzah in urinu (21). Vse bolnikove izločke s sumom ali potrjeno okužbo z novim koronavirusom (razen znoja) moramo zato obravnavati kot potencialno kužne (20).

S Kitajske prihajajo prva poročila o morebitnem vertikalnem prenosu $z$ dobrim izidom bolezni pri vseh novorojenčkih (22). Primerov prenosa virusa s transfuzijo darovane krvi za zdaj ni. Prav tako še ne vemo, ali se SARS-CoV-2 lahko prenaša z materinim mlekom, saj med hranjenjem zaradi tesnega stika lahko pride do kapljičnega prenosa (23).
V Sloveniji smo prvi primer okužbe s SARS-CoV-2 potrdili 4. marca 2020. Do konca maja je bilo potrjeno okuženih 1473 ljudi, od tega 48 otrok (9: 0-4 leta, 27: 5-14 let in 12: 14-18 let) (24).

\section{Patogeneza}

Patogeneza covid-19 še ni dobro raziskana, a spominja na SARS, saj SARS -CoV-2 za vstop v celice uporablja enak receptor, tj. ACE-2 (angl. angiotensin -converting enzyme 2). Izražanje receptorja v človeškem telesu lahko kaže na možne poti okužbe $(25,26)$. Visoko izraženost receptorja so ugotovili v alveolnih celicah tipa II pljuč (AT2), epitelnih celicah požiralnika, absorpcijskih enterocitih ileuma in debelega črevesa, holangiocitih, miokardnih celicah, celicah proksimalnih tubulov ledvic in urotelnih celicah mehurja (25). Receptor je izražen tudi na tkivih testisov, zato potekajo raziskave o škodljivosti SARS -CoV-2 za tkiva testisov, kar bi pri mladih bolnikih lahko pomenilo težave $s$ plodnostjo (26).

Domnevajo, da primarno razmnoževanje virusa poteka v sluznici epitela zgornjih dihalnih poti, nadaljnje razmnoževanje pa v sluznicah spodnjih dihal in prebavil. Hitro virusno razmnoževanje, upad oziroma odstranjevanje ACE-2 in s protitelesi okrepljen vstop virusa v celice so odgovorni za agresiven potek vnetja (27). Pride do masivnih poškodb in posledično apoptoze epitelnih in endotelnih celic, disfunkcije osi renin-angiotenzin ter s tem povečanja vnetja in žilne prepustnosti. O imunskih odzivih za zdaj ni veliko znanega. Pri težjih oblikah bolezni opažamo zavoro pridobljenega imunskega odziva in neobvladano aktivacijo prirojenega odziva, pri bolnikih z neugodnim izidom bolezni pa močno povečane serumske koncentracije proinflamatornih citokinov (citokinska nevihta) $(4,28)$.

Za covid-19 zbolevajo otroci redkeje kot odrasli. Bolezen pri njih poteka v blažji obliki, za kar obstaja več teorij. 
Glavna razloga naj bi bila drugačen imunski sistem z manjšim proinflamantornim citokinskim odgovorom v primerjavi z odraslimi ter manj izražen receptor $A C E-2$ z manjšo afiniteto za vezavo virusa. Možno je tudi, da imajo otroci zaradi hkratne kolonizacije z drugimi virusi in bakterijami ter prisotnosti protiteles proti ostalim koronavirusom manjšo možnost kolonizacije in okužbe s SARS-CoV-2. Poleg tega imajo otroci manj kroničnih bolezni, ki vplivajo težji potek covid-19 $(4,28,29)$.

\section{Klinična slika}

Za covid-19 lahko zbolijo otroci vseh starosti, vključno z novorojenčki. Inkubacija je 2-14 dni, v povprečju 4-6 dni (30). Bolezen se pri otrocih večinoma kaže z nespecifičnimi simptomi in znaki akutne virusne okužbe dihal, lahko pa so pridruženi gastrointestinalni simptomi. Povišana telesna temperatura ni vedno prisotna. Okužbo so potrdili tudi v primerih vročinskega stanja brez znakov okužbe zgornjih dihal (31).

\section{Simptomi in znaki}

Rezultati metaanalize objavljenih raziskav kažejo, da sta najpogostejši manifestaciji covid-19 pri otrocih vročina (32-82,2 \%) in kašelj (19-54 \%), ki sta prisotna $v$ manjšem deležu kot pri odraslih bolnikih (vročina pri približno 88 \% bolnikov in kašelj pri 57,6-68,6 \%) (31-36). Znake okužbe zgornjih dihal (faringitis in izcedek iz nosu) opisujejo pri manj kot tretjini otrok, okuženih s SARS-CoV-2. Najvišjo pojavnost tahipneje $(28,7 \%)$ navajajo $v$ raziskavi iz mesta Wuhan, a je dodatek kisika vdihanemu zraku zaradi nižjih vrednosti saturacije $\left(\mathrm{SpO}_{2}<92 \%\right)$ potrebovalo le 2,3\% otrok (31). Pri otrocih pogosteje kot pri odraslih (5\%) opisujejo prebavne težave (5-13\%). Medtem, ko so motnje vonja in okusa pogost (>85\%) in v več kot $10 \%$ prvi znak covid-19 pri odraslih, pa tuje populacijske raziskave pri otrocih teh simptomov ne navajajo. Klinično sliko in laboratorijske izvi-

\begin{tabular}{|c|c|c|c|c|c|}
\hline Klinični znaki & $\begin{array}{r}\text { Lu } \\
\text { et al. }{ }^{31}\end{array}$ & $\begin{array}{r}\text { Qui } \\
\text { et al. }{ }^{32}\end{array}$ & $\begin{array}{l}\text { Götzinger } \\
\text { et al } \text { al }^{-33}\end{array}$ & $\begin{array}{r}\text { Garazzino } \\
\text { et al. }{ }^{34}\end{array}$ & $\begin{array}{l}\text { Bialek } \\
\text { et al. }{ }^{35}\end{array}$ \\
\hline & $N(\%)$ & $N(\%)$ & $\mathrm{N}(\%)$ & $N(\%)$ & $N(\%)$ \\
\hline $\begin{array}{l}\text { število vključenih } \\
\text { otrok }\end{array}$ & 171 & 36 & 590 & 168 & 291 \\
\hline $\begin{array}{l}\text { brezsimptomne } \\
\text { okužbe }\end{array}$ & $39(23)$ & $10(28)$ & $92(15,6)$ & $4(2,5)$ & NP \\
\hline $\begin{array}{l}\text { vročina } \\
\text { definicija }\end{array}$ & $\begin{array}{r}55(32) \\
>38^{\circ} \mathrm{C}\end{array}$ & $\begin{array}{r}13(36) \\
\geq 37,5^{\circ} \mathrm{C}\end{array}$ & $\begin{array}{r}387(65,5) \\
N P\end{array}$ & $\begin{array}{r}138(82,1) \\
>37,5^{\circ} \mathrm{C}\end{array}$ & $\begin{array}{r}163(73) \\
\mathrm{NP}\end{array}$ \\
\hline kašelj & $83(49)$ & $7(19)$ & NP & $82(48,8)$ & $158(54)$ \\
\hline faringitis & $79(46)$ & $2(6)$ & NP & $9(5,4)$ & $71(24)$ \\
\hline izcedek iz nosu & $13(8)$ & NP & NP & $45(26,8)$ & $21(7,2)$ \\
\hline tahipneja & $49(28,7)$ & $1(3)$ & NP & $16(9,5)$ & NP \\
\hline piskanje & 0 & NP & NP & NP & NP \\
\hline driska & $15(9)$ & $2(6)$ & NP & $22(13,1)$ & $37(13)$ \\
\hline bruhanje & 0 & $2(6)$ & NP & $9(5,4)$ & $31(11)$ \\
\hline glavobol & NP & $3(8)$ & $72(27,5)$ & NP & $81(28)$ \\
\hline utrujenost & $13(8)$ & NP & NP & $3(1,8)$ & NP \\
\hline bolečine v mišicah & NP & NP & NP & NP & $66(23)$ \\
\hline bolečine v trebuhu & NP & NP & NP & NP & $17(5,8)$ \\
\hline $\begin{array}{l}\text { bolečine v prsnem } \\
\text { košu }\end{array}$ & NP & NP & NP & $4(2,4)$ & NP \\
\hline konjunktivitis & NP & NP & NP & $6(3,6)$ & NP \\
\hline $\begin{array}{l}\text { znaki okužbe } \\
\text { zgornjih dihal }\end{array}$ & NP & NP & $318(53,9)$ & NP & NP \\
\hline \multicolumn{6}{|c|}{ Laboratorijske preiskave } \\
\hline $\begin{array}{l}\text { levkociti }(\times 109 / L) \\
\text { nižje vrednosti }\end{array}$ & $\begin{array}{r}6,8(5,5-8,2) \\
<5,5 ; 45(26,3 \%) \\
\end{array}$ & $\begin{array}{r}6,1(4-8,2) \\
<4 ; 7(11 \%) \\
\end{array}$ & NP & NP & NP \\
\hline $\begin{array}{l}\text { nevtrofilni } \\
\text { granulociti (x 10\%/L) }\end{array}$ & $2,5(1,8-3,7)$ & NP & NP & NP & NP \\
\hline $\begin{array}{l}\operatorname{limfociti}\left(\times 10^{9} / L\right) \\
<1,2\end{array}$ & $\begin{array}{r}2,9(2,2-4,4) \\
6(3,5 \%)\end{array}$ & $\begin{array}{r}2,4(1,6-3,2) \\
11(31 \%)\end{array}$ & NP & NP & NP \\
\hline $\mathrm{PCT} \mu \mathrm{g} / \mathrm{L}$ & $0,05(0,04-0,08)$ & $\begin{array}{r}0,24(0,07 \\
-0,41) \\
\end{array}$ & NP & NP & NP \\
\hline $\begin{array}{l}\text { C-reaktivni protein } \\
\mathrm{mg} / \mathrm{L}\end{array}$ & $4,0(1,3-8,0)$ & $5(3-7)$ & NP & NP & NP \\
\hline LDH $\mu \mathrm{kat} / \mathrm{L}$ & $4,1(3,45-5,08)$ & NP & NP & NP & NP \\
\hline ALT $\mu \mathrm{kat} / \mathrm{L}$ & $0,25(0,18-0,45)$ & $\begin{array}{r}0,35 \\
(0,11-0,58)\end{array}$ & NP & NP & NP \\
\hline AST $\mu \mathrm{kat} / \mathrm{L}$ & $0,5(0,4-0,7)$ & $0,5(0,31-0,68)$ & NP & NP & NP \\
\hline$D$-dimer $\mu \mathrm{g} / \mathrm{L}$ & $0,2(0,2-0,4)$ & $\begin{array}{r}0,29 \\
(0,09-0,49)\end{array}$ & NP & NP & NP \\
\hline
\end{tabular}

TABELA 1. KLINIČNA SLIKA OTROK S COVID-19.

TABLE 1. CLINICAL FEATURES OF COVID-19 IN CHILDREN.

Legenda: N - število, NP - ni podatka. 


\begin{tabular}{ll} 
Klasifikacija & Klinična slika \\
\hline brezsimptomna & $\begin{array}{l}\text { pozitiven bris nosno-žrelnega prostora na SARS-CoV-2, brez simptomov in } \\
\text { znakov okužbe }\end{array}$ \\
\hline blaga & znaki okužbe zgornjih dihal ali prebavne težave, brez pljučnice \\
\hline zmerna & pljučnica brez hipoksemije \\
\hline huda & pljučnica s hipoksemijo (oteženo dihanje, centralna cianoza) \\
\hline kritična & $\begin{array}{l}\text { odpoved dihanja (lahko ARDS), šok, znaki večorganske odpovedi (npr. } \\
\text { encefalopatija, odpoved srca, motnje strjevanja krvi, akutna odpoved ledvic }\end{array}$ \\
\hline
\end{tabular}

TABELA 2: KLINIČNA KLASIFIKACIJA STOPNJE COVID-19 (38).

TABLE 2: COVID-19 SEVERITY CLASIFICATION (38).

Legenda: ARDS - akutni sindrom dihalne stiske (angl. acute respiratory distress syndrome). de otrok s covid-19, opisane $v$ različnih raziskavah, prikazujemo v Tabeli 1 .

Vsi slovenski otroci, pri katerih so dokazali okužbo s SARS-CoV-2, so prebolevali bolezen v blagi obliki in niso potrebovali bolnišničnega zdravljenja. Najpogostejši simptomi in znaki so bili vročina, suh kašelj, glavobol, utrujenost in prehladni znaki.

V povezavi s covid-19 opisujejo tudi različne kožne spremembe. Najpogostejši so t. i. covid prsti ter akutna akroishemija prstov rok in nog, ki spominja na ozebline. Večinoma so prisotni pri blažjem poteku bolezni, spremembe pa $v$ nekaj tednih brez posledic spontano izzvenijo. Natančne patogeneze še ne poznamo (37).

\section{Klinična klasifikacija stopnje bolezni}

Klinična klasifikacija stopnje bolezni temelji na petih kategorijah, ki jih prikazujemo v Tabeli 2 (38).

V največji objavljeni raziskavi, opravljeni na Kitajskem, so pri 731 otrocih s covid-19 ugotovili, da $12,9 \%$ otrok preboleva covid-19 brez simptomov in znakov okužbe, medtem ko ima 43,1 \% otrok blago obliko bolezni, $41 \%$ zmerno obliko bolezni, 2,5\% hudo obliko bolezni in $0,4 \%$ otrok kritično obliko bolezni (39). Za hudo in kritično sliko bolezni večkrat zbolevajo otroci s pridruženimi boleznimi $(4,35,40)$. $\vee$ kitajski raziskavi je Lu s sodelavci ugotavljal CT spremembe, značilne za pljučnico covid-19, v skoraj $65 \%$, a je le 2,3\% otrok potrebovalo zdravljenje s kisikom (31).

Iz dosedanjih raziskav lahko zaključimo, da večina otrok preboleva bolezen $v$ blagi in zmerni obliki. Le nekaj odstotkov otrok ima hudo in kritično obliko bolezni, a zaradi različno zasnovanih raziskav, podatkov o pravi pojavnosti nimamo.

\section{Covid-19 pri novorojenčkih}

Izsledki 11 manjših raziskav in poročil s Kitajskega, ki so vključevali 67 novorojenčkov, so pri novorojenčkih covid-19 pozitivnih mater, ki so bili v $88 \%$ rojeni s carskim rezom, v $38 \%$ ugotavljali prezgodnji porod. Pri zapletih novoro- jenčkov so prevladovali akutni sindrom dihalne stiske in pljučnica v $18 \%$, nizka porodna teža v $13 \%$, izpuščaj v $3 \%$, diseminirana intravaskularna koagulacija v $3 \%$, asfiksija v $2 \%$ in perinatalna smrt v $3 \%$. Večina novorojenčkov je imela več zaporednih brisov na SARS -CoV-2 negativnih (29).

Covid-19 pri otrocih s kroničnimi boleznimi in pri imunsko oslabelih

Zaradi majhnega števila bolnikov med otroki s kroničnimi boleznimi in hudo bolnih otrok s covid-19 dejavnikov tveganja za hujši potek še ne poznamo natančno $(31,34,35)$. Otroci z osnovnimi kroničnimi boleznimi, kot so kronične pljučne bolezni, kronična vnetna črevesna bolezen in rakave bolezni, ter imunsko oslabeli otroci so večinoma prebolevali blago do zmerno obliko bolezni. Iz 102 centrov za obravnavo kroničnih vnetnih črevesnih bolezni pri otrocih so poročali o skupaj 8 okuženih bolnikih, vseh z blago obliko okužbe. Tudi pri petih pediatričnih onkoloških bolnikih iz Italije je bil potek bolezni blag in nihče ni prejemal protivirusnega zdravljenja $(41,42)$. Podatki Evropskega respiratornega združenja prav tako kažejo, da kronične pljučne bolezni pri otrocih, kot sta astma in cistična fibroza, ne pomenijo večjega tveganja za hujši potek bolezni (43), a so zdravljenje $v$ intenzivni enoti največkrat potrebovali otroci s pridruženimi boleznimi in novorojenčki $(4,40)$.

\section{Napoved izida bolezni}

Bolezen je samoomejujoča in jo večina otrok preboli brez posledic $v$ 1-2 tednih po nastopu bolezni (44). $\mathrm{V} \mathrm{kli-}$ ničnem poteku lahko $v$ drugem tednu nastopi poslabšanje s tiho hipoksemijo, ob kateri bolnik ne čuti težjega dihanja, in lahko hitro privede do dihalne odpovedi (12).

Smrtnost zaradi covid-19 je pri otrocih verjetno zelo nizka. $V$ literaturi trenutno opisujejo le posamezne primere smrti pri otrocih, ki so večinoma imeli težje osnovne bolezni $(4,31,34,40)$. 
Večorganski vnetni sindrom pri otrocih v povezavi s covid-19

Iz evropskih držav z visoko razširjenostjo covid-19 in iz ZDA so se konec aprila pričeli pojavljati opisi otrok s hudim vnetnim sistemskim odzivom, ki lahko vodi v šokovno stanje, ter se kaže s prekrivajočimi se znaki Kawasakijeve bolezni in sindroma toksičnega šoka $(45,46)$. Po podatkih iz literature je imelo več otrok potrjeno okužbo s SARS-CoV-2 ali pozitivno epidemiološko anamnezo (45-47). Zato je SZO pozvala k enotnemu zbiranju podatkov in 15. maja 2020 podala prvo definicijo t. i. s covid-19 povezanega večorganskega vnetnega sindroma pri otrocih in najstnikih (angl. multisystem inflammatory syndrome in children, MIS-C ali angl. pediatric multisystem inflammatory syndrome, PMIS), za katerega morajo biti izpolnjeni naslednji pogoji: vročina več kot tri dni IN vsaj dva klinična znaka (izpuščaj/negnojni konjunktivitis/eksantem dlani, podplatov, enantem ustne sluznice; znižan krvni tlak ali šokovno stanje; znaki prizadetosti srca; motnje v strjevanju krvi ali težave s strani prebavil) IN povišani laboratorijski kazalniki vnetja IN negativni izvidi preiskav na ostale povzročitelje okužb IN pozitiven bris, protitelesa ali kontakt s covid-19 (47).

Natančna povezava s covid-19 še ni pojasnjena, a so nedavno opisali pojav redke mutacije evropskega seva SARS-CoV-2, zaradi katere ima virus lastnosti superantigena, kar povzroči nenadzorovano aktivacijo limfocitov $T$ in citokinsko nevihto, ki vodi v toksični šok (48).

\section{Laboratorijske in slikovne preiskave}

Medtem ko so visoke vrednosti CRP, izrazita limfopenija ter visoke vrednosti D-dimera, LDH, CK in feritina napovedni dejavniki hujšega poteka pri odraslih, za otroke zanesljivih podatkov zaradi majhnega števila objavljenih raziskav o otrocih s hudo ali kritično klinično sliko covid-19 nimamo (12).

Pri bolnih otrocih s covid-19 izvidi laboratorijskih preiskav niso značilni. V pregledni raziskavi, v kateri so Henry in sodelavci povzeli 12 raziskav s skupaj 66 vključenimi otroki, obolelimi za covid-19, je imelo 69,2 \% otrok normalno število levkocitov, le $6 \%$ otrok nevtropenijo in samo $3 \%$ limfopenijo oz. trombocitopenijo. Vrednost CRP je bila povišana v 13,6 \%, PCT pa v 10,6 \% (49).

Na rentgenskem posnetku pljuč so prisotni večinoma obojestranski intersticijski infiltrati, ki so na začetku bolezni pretežno na periferiji pljuč, z napredovanjem bolezni pa se širijo centralno. Tudi na posnetku CT so v zgodnji fazi vidne številne intersticijske spremembe, ob slabšanju stanja pa se pojavijo obojestranski infiltrati videza mlečnega stekla. Pri težjem poteku je lahko prisotna zgostitev pljuč, plevralni izliv pa je redek (31).

\section{Dokazovanje}

Znanje o pomenu diagnostičnih testov se še vedno nadgrajuje, saj sta njihova razumevanje in razlaga $v$ povezavi s klinično sliko zelo pomembna za razumevanje kužnosti bolnika.

\section{Verižna reakcija s polimerazo v realnem času}

Ker je pomembno hitro diagnosticiranje, je preiskava izbire za potrditev akutne okužbe neposreden dokaz virusa. Zaenkrat najpogosteje uporabljen test za dokaz okužbe s SARS-CoV-2 je verižna reakcija s polimerazo $v$ realnem času (angl. real time polymerase chain reaction, $\mathrm{RT}$-PCR). Vzorec, ki ga najpogosteje uporabljamo, je bris nosno-žrelnega prostora. Različni proizvajalci testov uporabljajo različne tarčne RNK-gene SARS-CoV-2. Specifičnost testa je praktično $100 \%$. Lažno pozitiven test je lahko posledica tehnične napake ali kontaminacije, medtem ko so lažno negativni rezultati lahko pos- ledica nepravilno odvzetega brisa ali premajhne količine virusa v kužnini (kar so opažali pri bolnikih, ki so prišli $v$ bolnišnico relativno pozno, običajno z napredovalo okužbo spodnjih dihal - covid-19 pljučnico) $(12,50)$.

Test je pozitiven že prvi dan ob pojavu bolezenskih znakov, in ima najvišje virusno breme v prvem tednu bolezni, nato pa se postopno zmanjšuje. Po tretjem tednu je bris negativen pri večini bolnikov, ki so preboleli blago obliko bolezni, in takrat tudi pozitiven rezultat ne pomeni nujno prisotnosti živega virusa. V nekaterih primerih lahko pozitiven bris vztraja več kot 6 tednov. Znani so tudi primeri, ko se je pozitiven bris ponovno pojavil po dveh negativnih izvidih, a še ni jasno, ali gre za laboratorijsko napako, ponovno okužbo ali reaktivacijo (51). Po mnenju južnokorejskih zdravnikov gre verjetno za zaznavanje RNK mrtvih virusov, saj so bile pri 108 bolnikih virusne kulture negativne (52). Po podatkih tajvanske prospektivne raziskave je največja prenosljivost SARS-CoV-2 nekaj dni pred in po pojavu simptomov in znakov (53).

Wang s sodelavci je pri bolnikih s covid-19 raziskoval prisotnost virusa $v$ različnih tkivih in telesnih tekočinah. Največ pozitivnih rezultatov je dokazal pri vzorcih, pridobljenih z bronhoalveolnim izpiranjem (93\%). Sledili so izpljunki (72 \%). Bris nosno-žrelnega prostora je bil pozitiven v $63 \%$, bris žrela pa le v $32 \%$ (54). V raziskavi so dokazali prisotnost virusa tudi v drugih telesnih izločkih - blatu (29 \%) in krvi ( $1 \%), v$ eni od kasnejših raziskav pa tudi v urinu $(21,54)$. Pozitiven rezultat je ovrednoten pri vrednosti CT manj kot 40. Virus so pri dveh bolnikih osamili iz blata, kar bi lahko pomenilo, da se širi tudi po fekalnooralni poti. Pozitivni izvidi vzorcev krvi kažejo, da lahko bolezen poteka tudi z viremijo (54).

\section{Serološke preiskave}

Serološke preiskave imajo klinični pomen le pri bolnikih z blago obliko 
bolezni, ki pridejo do zdravnika več kot dva tedna po začetku okužbe, in nam pomagajo razumeti razširjenost SARS-CoV-2 v populaciji, saj nekateri ljudje bolezen prebolijo brez simptomov. Protitelesa IgM in IgG pričnejo nastajati po prvem tednu bolezni ter so med tretjim in petim tednom prisotna pri vseh zbolelih (55). Protitelesa IgM običajno izginejo do sedmega tedna, protitelesa IgG pa vztrajajo dlje. Testi ELISA IgM in IgG imajo pri diagnosticiranju covid-19 več kot 95-odstotno specifičnost. Najbolj občutljivi so testi, ki ugotavljajo specifična protitelesa proti proteinu NC, najbolj specifični pa testi, ki ugotavljajo prisotnost specifičnih protiteles proti koničastim proteinom $S$ (50). Pomanjkljivost seroloških testov je navzkrižna reaktivnost z drugimi koronavirusi. Kolikšna je imunost po preboleli okužbi, zaenkrat še ni znano, a nekateri rezultati nakazujejo, da se po okužbi lahko izoblikuje učinkovit specifični imunski odziv, ki vsaj začasno prepreči njeno ponovitev (12).

\section{Zdravljenje}

V luči nastajajoče globalne zdravstvene krize, ki jo je povzročila pandemija covid-19, se stopnjujejo napori za iskanje novih ali za zdravljenje drugih bolezni uveljavljenih zdravil, ki bi omilila potek bolezni. Dostopni podatki o potencialno učinkovitih zdravilih temeljijo predvsem na raziskavah in vitro, raziskavah na živalskih modelih in raziskavah na majhnem številu odraslih bolnikov. Zaenkrat specifičnega zdravila za okužbo s SARS-CoV-2 ni, zato so ukrepi usmerjeni v podporno zdravljenje, kar je glede na večinoma blag potek bolezni pri otrocih povsem ustrezno. Pri otrocih s hudim in kritičnim potekom bolezni svetujejo strukturiran pristop za odločitev o uvedbi protivirusnih zdravil. Pretehtati moramo koristi in tveganja za vsak posamezen primer ter upoštevati stopnjo bolezni in nevarnost nadaljnjega slabšanja stanja. Pri bolnikih s potrjeno okužbo (razen pri kritično bolnih) sve- tujejo uvedbo zdravil v sklopu kliničnih raziskav, seveda v soglasju z infektologi ter ob skrbnem kliničnem in laboratorijskem spremljanju bolnika (56).

Kot najobetavnejše protivirusno zdravilo se je doslej izkazal remdesivir, monofosforamidatno predzdravilo za analog adenozina (56-58). Nastal je kot odgovor na izbruh ebole v Zahodni Afriki v letih 2014-2016 in ima široko protivirusno delovanje. Remdesivir z izogibanjem virusni eksoribonukleazi povzroči prezgodnji konec transkripcije virusne RNK (57). Klinični potencial pri zdravljenju okužbe s SARS-CoV-2 je izhajal iz poskusov na opicah Rhesus, pri katerih so $v$ limfocitih v periferni krvi po vbrizganju zdravila dosegli visoke znotrajcelične koncentracije aktivne trifosfatne oblike (56-58). Trenutno potekajo številne raziskave, ki vključujejo odrasle bolnike s covid-19, otrok, mlajših od 12 let, pa ne. Uporaba remdesivirja je možna preko mehanizma prošnje za sočutno rabo, ki je za posameznega bolnika naslovljena na proizvajalca (57). Izsledki dvojno slepe randomizirane kontrolirane raziskave o uporabi remdesivirja pri 1059 odraslih bolnikih s covid-19 s prizadetostjo spodnjih dihal so potrdili njegovo učinkovitost, saj so bolniki okrevali hitreje kot kontrolna skupina (11 dni proti $15 \mathrm{dni}$ ). Tudi smrtnost do 14. dneva je bila v skupini zdravljenih bolnikov manjša v primerjavi s skupino, ki je prejemala placebo (7,1 \% proti $11,9 \%$ ), pojavnost neželenih učinkov pa primerljiva (59).

Lopinavir je inhibitor virusne proteaze in uveljavljeno zdravilo za zdravljenje z bolnikov s kronično okužbo s HIV. Uporabljamo ga v kombinaciji z ritonavirom, ki zvišuje koncentracijo lopinavira. Izsledki randomizirane klinične raziskave na vzorcu 199 odraslih bolnikov s hudo obliko bolezni niso pokazali, da bi bilo zdravljenje z lopinavir/ ritonavirjem bolj učinkovito od standardnega podpornega zdravljenja (60).

Klorokin je uveljavljeno zdravilo za zdravljenje malarije, zaradi protivnetnih in imunomodulatornih učinkov pa ga uporabljamo tudi za zdravljenje revmatoidnega artritisa in sistemskega eritematoznega lupusa. Kljub obetavnim izsledkom raziskav in vitro je njegova uporaba pri zdravljenju bolnikov s covid-19 nenamenska (61). Do sedaj se ni izkazal kot učinkovito zdravilo za katero koli akutno virusno okužbo pri človeku. Hidroksiklorokin je in vitro močnejši kot klorokin, a hkrati manj dovzeten za interakcije z zdravili. Kombinacija z azitromicinom, ki zviša serumsko koncentracijo hidroksiklorokina, naj bi bila sprva alternativa remdesivirju, a obe zdravili podaljšujeta dobo QTc. Uporaba hidroksiklorokina naj bi bila upravičena pri otrocih, za katere zdravljenje $z$ remdesivirjem ni primerno, ali če remdesivirja ni na voljo, medtem ko hkratno uporabo azitromicina odsvetujejo (56). Izrazita previdnost je zaradi nevarnosti hipoglikemije potrebna pri bolnikih s sladkorno boleznijo, pri hkratni uporabi zdravil, ki podaljšujejo dobo QTc, in zaradi nevarnosti hemolize pri bolnikih s pomanjkanjem glukoza-6-fosfat dehidrogenaze (56).

Favipiravir je inhibitor od RNK odvisne RNK polimeraze. In vitro je učinkovit proti virusom gripe $A, B$ in $C$, ki so odporni na oseltamivir. Preliminarni izsledki kliničnih raziskav so pokazali učinkovitost pri zdravljenju bolnikov s covid-19 na Kitajskem (57).

\section{Druge možnosti zdravljenja}

Deksametazon je kortikosteroid, ki na več ravneh zavira imunski odgovor. Izsledki prospektivne, randomizirane, s placebom kontrolirane raziskave RECOVERY so pokazali, da je zdravljenje z nizkim odmerkom deksametazona pri bolnikih s pljučnico covid-19 in potrebo po kisiku pomembno zmanjšalo smrtnost. Najboljši učinek ugotavljajo pri bolnikih na umetnem predihavanju ali na podpori z zunajtelesno membransko oksigenacijo, a je bilo v raziskavo vključeno majhno število otrok. Izsledkov drugih kliničnih raziskav, ki bi vrednotili učinkovitost zdravljenja z deksametazonom pri otrocih s pljučni- 
co covid-19, še ni, zato je pri prenosu izsledkov raziskave RECOVERY na otroško populacijo potrebna previdnost. Pri odločitvi o zdravljenju moramo pretehtati koristi in tveganja za vsak posamezen primer (62).

$\checkmark$ preteklosti se je pri zdravljenju virusnih okužb, na primer pri SARS, MERS, eboli in pandemski gripi H1N1, kot učinkovito izkazalo zdravljenje s transfuzijo prebolevniške plazme. Protitelesa iz plazme prebolevnikov naj bi zmanjševala viremijo, preprečevala nadaljnje okužbe celic in izboljšala odstranjevanje okuženih celic. Teoretično naj bi bilo zdravljenje s prebolevniško plazmo najbolj učinkovito v zgodnjem obdobju bolezni - v času viremije in pred razvojem primarnega imunskega odziva. Izsledki raziskave na majhnem številu kitajskih bolnikov kažejo pozitivne učinke, a so poleg plazme prejemali še protivirusna zdravila in steroide (63).

Bolnike z MIS-C so zdravili z intravenskimi imunoglobulini in visokimi odmerki steroidov, ob neučinkovitosti pa $z$ anakinro, ki je antagonist receptorja za IL-1, in tocilizumabom, ki je monoklonsko protitelo proti receptorjem za IL-6. Tocilizumab so kot zdravilo za bolnike s hudim ali kritičnim potekom bolezni in zvišano koncentracijo IL-6 uporabljali tudi med izbruhom covid-19 na Kitajskem $(46,57,58)$.

\section{Cepljenje}

Nukleotidni zapis SARS-CoV-2 je v približno v $89 \%$ podoben nukleotidnemu zapisu koronavirusov, podobnih SARS -u, zato prizadevanja za razvoj cepiva proti SARS-CoV-2 temeljijo na dosedanjem razvoju cepiv proti SARS-u (64). Glavna strategija razvoja cepiva je usmerjena proti glikoproteinu $S$, ki se nahaja na površini virusa in je najpomembnejši za nastanek nevtralizirajočih protiteles (65). Največ raziskovalcev razvija cepiva, ki vsebujejo rekombinantne podenote virusa (beljakovino S ali le njen del S1, dru- ge podenote virusa), oslabljen/inaktiviran virus in nukleinske kisline virusa $(64,65)$. Cepiva za uporabo še nimamo. Po podatkih SZO je v času pisanja prispevka, dne 30. maja 2020, v fazi kliničnega preizkušanja deset zdravil. Izmed njih eno prehaja v tretjo fazo, dve cepivi sta v drugi fazi, 121 cepiv pa je v predklinični fazi preizkušanja (66).

Ker je v zadnjih 20 letih to že tretja epidemija koronavirusne okužbe, pomen razvoja cepiv proti koronavirusom ni le v obvladovanju oz. omejitvi trenutne epidemije, ampak tudi v preprečevanju podobne epidemije $v$ prihodnje (64). Ker gre za cepiva, ki so uporabna zgolj ob eni epidemiji, je relativno zanimanje farmacevtskih podjetij za njihov razvoj zanemarljivo (65).

\section{Ukrepi za preprečevanje širjenja okužbe z novim koronavirusom}

Za zmanjšanje možnosti vnosa in širjenja okužbe med bolniki in zdravstvenimi delavci so številne organizacije objavile priporočila za pripravo zdravstvenih ustanov in sistemov na izbruh SARS-CoV-2. Med najpomembnejšimi prvimi ukrepi sta zagotovitev, da bolniki s sumom na covid-19 ne prihajajo nenadzorovano $v$ zdravstvene ustanove, in zagotovitev ustreznih izolacijskih prostorov za njihovo obravnavo. $\mathrm{Na}$ ravni primarnega zdravstva naj bi ustanovili vstopne ambulante, $v$ bolnišnicah pa ločene oddelke covid-19. Aktiviranje ostalih načrtov za izredne razmere $v$ bolnišnicah vključuje tudi preklic nenujnih operacijskih posegov in nenujnih kontrolnih pregledov, prerazporeditev zdravstvenega osebja, zmanjšanje administrativnega dela zdravstvenih delavcev, preureditev neintenzivnih prostorov $v$ oddelke intenzivne nege in terapije, določitev osebja, ki bo oskrbovalo bolnike s covid-19, optimizacijo uporabe zaščitne opreme, zmanjšanje premikanja bolnikov znotraj bolnišnice, načrt za širjenje prostorov v primeru pomanjkanja prostora $v$ bolnišnicah (šotori, zabojniki, vojaške bolnišnice itd.), zagotovitev samoizolacije za bolnike, ki ne potrebujejo bolnišničnega zdravljenja, in karantena za stike z osebami okuženimi s SARS-CoV-2 $(67,68)$.

Pri vseh obravnavah $v$ zdravstvenih ustanovah moramo upoštevati standardne ukrepe, ki so namenjeni predvsem zaščiti zaposlenih pred okužbami. Za preprečevanje širjenja okužb $v$ bolnišničnem okolju so pri obravnavi bolnikov, ki imajo potrjeno okužbo s covid-19 ali sum nanjo, posebej pomembna naslednja načela (67):

1. dobra triaža, zgodnje prepoznavanje možnih primerov in osamitev bolnikov s sumom na covid-19;

2. uporaba že dobro znanih in utemeljenih standardnih ukrepov s poudarkom na dosledni higieni rok in higieni kašlja ter pravilni uporabi osebne varovalne opreme (OVO), ki se uporablja glede na priporočila mednarodnih strokovnih združenj, kot sta SZO in ECDC (angl. European centre for disease prevention and control). Ob tem upoštevamo oceno tveganja, ki temelji na intenzivnosti stika in vrsti posega pri bolniku. V Evropi upoštevamo priporočila ECDC, ki jih je prevzel tudi Nacionalni inštitut za javno zdravje (NIJZ). Po priporočilih je ključna zaščita sluznic oči in dihal, saj virus preko njih vstopa v telo. Zaposleni morajo pri delu vedno uporabljati očala ali vizir in zaščitno masko. Vse izločke bolnika s sumom na okužbo SARS-CoV-2 ali potrjeno okužbo (razen znoja) moramo obravnavati kot potencialno kužne (69).

3. Izvajanje dodatnih izolacijskih ukrepov, kot so ukrepi kapljične in kontaktne izolacije, ter ob indikaciji tudi aerogene izolacije.

4. Priprava pisnih navodil za zaposlene $v$ zvezi s celotno obravnavo bolnikov s covid-19 (sprejem, pregledi in preiskave, čiščenje in razkuževanje pripomočkov, inštrumentov, in površin, rokovanje s hrano, odstranjevanje odpadkov, prevoz in pra- 
nje perila, varno rokovanje z ostrimi predmeti, varno delo v laboratorijih, varno delo ob oživljanju ipd.).

5. Izvajanje administrativnih ukrepov in nadzora: izobraževanje zdravstvenega osebja, preverjanje znanja in upoštevanja uporabe OVO in higiene rok, zagotavljanje ustrezne zaloge OVO in razkužil, navodila zaposlenim glede zagotavljanja namenskih čakalnih območij za simptomatske bolnike, prepoved obiskov, nadzor nad zdravjem zaposlenih ipd.

6. Nadzor okolja: ustrezno prezračevanje, čiščenje in razkuževanje, vključno z rednim mikrobiološkim vzorčenjem. Preživetje virusa je odvisno od temperature in od vrste površine. $V$ zadnjih eksperimentalnih raziskavah so prisotnost virusa zaznali do 14 dni pri temperaturi $4^{\circ} \mathrm{C}$, en dan pri temperaturi $37{ }^{\circ} \mathrm{C}$ ter eno minuto pri temperaturi $70^{\circ} \mathrm{C}$. Glede na vrsto površine je virus sposoben preživeti do 30 minut na papirju in robčkih, dva dneva na bankovcih, štiri dni na plastiki in jeklu ter do 7 dni na zunanji plasti kirurške maske (70).

7. Izobraževanje in navodila bolnikom in njihovim svojcem glede ravnanja ob prihodu in odhodu iz zdravstvene ustanove.

\section{Zaključek}

Pandemija covid-19 je v začetku letošnjega leta za nekaj mesecev ohromila življenje po vsem svetu. Reorganizacija zdravstva je žal marsikje zmanjšala dostopnost do osnovnih zdravstvenih storitev, iz Italije pa so zaradi prepoznega obiska zdravnika poročali celo o smrtnih primerih pri otrocih (71). Kljub veliki zdravstveni in gospodarski škodi, ki jo je povzročil prvi val epidemije, pa ostaja pozitiven vtis, da bolezen zaenkrat vsaj pri otrocih ni povzročila hujše obolevnosti in smrtnosti. V preteklih mesecih smo se veliko naučili o preprečevanju prenosa, pomembnosti hitrega ukrepanja za zajezitev epi- demije, reorganizaciji zdravstvenih zavodov in optimalnem podpornem zdravljenju najbolj bolnih bolnikov, a ostaja še veliko neznank, predvsem kar se tiče imunosti po preboleli okužbi ter razvoja učinkovitega cepiva in protivirusnih zdravil. Drugi val epidemije jeseni je ob tako razširjeni bolezni zelo verjetno realna možnost, zato uživajmo poletje na varni razdalji.

\section{LITERATURA}

1. World Health Organisation. Coronavirus disease (COVID-19) Pandemic. Dosegljivo na: https://www.who.int/emergencies/diseases/ novel-coronavirus-2019.

2. World Health Organisation. WHO announces COVID-19 outbreak a pandemic. Dosegljivo na: http://www.euro.who. int/en/health-topics/health-emergencies/ coronavirus-covid-19/news/news/2020/3/ who-announces-covid-19-outbreak-a-pandemic. 3. World Health Organisation. Coronavirus disease (COVID-19). Situation Report - 132. Data as received by WHO from national authorities by 10:00 CEST, 31 May 2020. Dosegljivo na: https:// www.who.int/docs/default-source/coronaviruse/ situation-reports/20200531-covid-19-sitrep-132. pdf?sfvrsn=d9c2eaef_2.

4. Ludvigsson JF. Systematic review of COVID-19 in children shows milder cases and a better prognosis than adults. Acta Paediatr 2020; 109 (6): 1088-95.

5. Lai MMC, Cavanagh D. The molecular biology of coronaviruses. Adv Virus Res 1997; 48: $1-100$.

6. Chan JFW, To KKW, Tse H, Jin DY, Yuen KY. Interspecies transmission and emergence of novel viruses: Lessons from bats and birds. Trends Microbiol 2013; 21 (10): 544-55.

7. Corman VM, Muth $D$, Niemeyer $D$, Drosten C. Hosts and Sources of Endemic Human Coronaviruses. Adv Virus Res 2018; 100: 163-88.

8. Anderson LJ, Schneider E. Coronaviruses. In: Goldman L, Schafer A. (eds.) Goldman's Cecil Medicine. 24 ${ }^{\text {th }}$ edition. Philadelphia: Elsevier Health Sciences; 2012: 2102-2014.

9. Jevšnik $M$, Steyer $A$, Pokorn M, Mrvič T, Grosek Š, Strle F, et al. (2016) The Role of Human Coronaviruses in Children Hospitalized for Acute Bronchiolitis, Acute Gastroenteritis, and Febrile Seizures: A 2-Year Prospective Study. PLOS ONE 11 (5): e0155555

10. Strle F. SARS. V: Tomažič J, Strle F. (eds.) Infekcijske bolezni. 1. izdaja. Ljubljana: Združenje za infektologijo, Slovensko zdravniško društvo;

\section{4/2015: 300-302.}

11. World Health Organisation. Middle East respiratory syndrome coronavirus (MERSCoV). Dosegljivo na: https://www.who.int/ emergencies/mers-cov/en/

12. Tomažič J, Lejko-Zupanc T, Ihan A, Plankar Srovin T, Sočan M. Koronavirusna bolezen 2019: celovit klinični pregled. Zdrav Vestn 2020 [In press].

13. Chan JFW, Kok KH, Zhu Z, Chu H, To KKW, Yuan S, et al. Genomic characterization of the 2019 novel human-pathogenic coronavirus isolated from a patient with atypical pneumonia after visiting Wuhan. Emerg Microbes Infect 2020; 9 (1): 221-36

14. Cascella M, Rajnik M, Cuomo A, Dulebohn SC, Di Napoli R. Features, Evaluation and Treatment. Coronavirus (COVID-19). StatPearls 2020; 1-21. Dosegljivo na: https://www.ncbi.nlm.nih. gov/books/NBK554776/?report=classic.

15. Sanche $S$, Lin $Y T, X u C$, Romero-Severson E, Hengartner N, Ke R. High Contagiousness and Rapid Spread of Severe Acute Respiratory Syndrome Coronavirus 2. Emerg Infect Dis 2020; 26 (7): 14470-7.

16. Delamater PL, Street EJ, Leslie TF, Yang YT, Jacobsen KH. Complexity of the Basic Reproduction Number (RO). Emerg Infect Dis 2019; 25(1): $1-4$

17. Dong $Y, M o X, H u Y$, Qi $X$, Jiang $F$, Jiang $Z$, et al. Epidemiology of COVID-19 among children in China. Pediatrics 2020; 145(6): e20200702.

18. Wang $D$, Ju $X$, Xie F, Lu Y, Li FY, Huang HH, et al. Clinical analysis of 31 cases of 2019 novel coronavirus infection in children from six provinces (autonomous region) of northern China. Chin J Pediatr 2020; 58 (4): 269-274.

19. World Health Organisation. Coronavirus disease (COVID-19). Situation Report - 89. Data as received by WHO from national authorities by 10:00 CEST, 18 April 2020. Dosegljivo na: https:// www.who.int/docs/default-source/coronaviruse/ situation-reports/20200418-sitrep-89-covid-19. pdf.

20. European Center for Disease Control Infection prevention and control for COVID-19 in health care settings - Third update. 13 May 2020. Stockholm: ECDC; 2020. Dosegljivo na: https://www.ecdc.europa.eu/en/publicationsdata/infection-prevention-and-control-and-preparedness-covid-19-healthcare-settings.

21. Peng L, Liu J, Xu W, Luo Q, Chen D, Lei Z, et al. SARS-CoV-2 can be detected in urine, blood, anal swabs, and oropharyngeal swabs specimens. J Med Virol 2020; 10.1002/jmv.25936. Dosegljivo na: https://onlinelibrary.wiley.com/doi/ full/10.1002/jmv.25936.

22. Yang Z, Wang M, Zhu Z, Liu Y. Coronavirus disease 2019 (COVID-19) and pregnancy: a systematic review. J Matern Fetal Neonatal Med 2020; 30 (4): 1-4.

23. Chen H, Guo J, Wang C, Luo F, Yu X, Zhang $W$, et al. Clinical characteristics and intrauterine vertical transmission potential of COVID-19 infection in nine pregnant women: a retrospective review of medical records. The Lancet 2020; 395 (10226): 809-15.

24. Nacionalni institute za javno zdravje. Dnevno spremljanje okužb s SARS CoV2. Dosegljivo na: https://www.nijz.si/sl/ dnevno-spremljanje-okuzb-s-sars-cov-2-covid-19. 25. Zou X, Chen K, Zou J, Han P, Hao J, Han Z. Single-cell RNA-seq data analysis on the receptor ACE2 expression reveals the potential risk of different human organs vulnerable to $2019-\mathrm{nCoV}$ infection. Front Med 2020; 14 (2): 185-92. 
26. Fan C, Li K, Ding Y, Lu WL, Wang J. ACE2 Expression in Kidney and Testis May Cause Kidney and Testis Damage After 2019-nCoV Infection. Medrxiv [Preprint] 2020. Dosegljivo na: https://www.medrxiv.org/content/10.1101/2020. 02.12.20022418v1.

27. Fu Y, Cheng $Y$, Wu Y. Understanding SARS -CoV-2-Mediated Inflammatory Responses: From Mechanisms to Potential Therapeutic Tools. Virol Sin 2020; 1-6. Dosegljivo na: https://www.ncbi. nlm.nih.gov/pmc/articles/PMC7090474/.

28. Brodin P. Why is COVID-19 so mild in children? ActaPaediatr 2020; 109 (6): 1082-3.

29. Zimmermann P, Curtis N. COVID-19 in children, pregnancy and neonates: A review of epidemiologic and clinical features. Pediatr Infect Dis J 2020; 39: 469-77.

30. Lauer SA, Grantz KH, Qifang Bi, Jones FK, Zheng Q, Meredith HR, et al. The Incubation Period of Coronavirus Disease 2019 (COVID-19) From Publicly Reported Confirmed Cases: Estimation and Application. Ann Intern Med 2020; 172 (9): 577-582.

31. Lu X, Zhang L, Du H, Zhang J, Li YY, Qu J, et al. SARS-CoV-2 Infection in Children. N Engl J Med 2020; 382: 1663-5.

32. Qui H, Wu J, Hong L, Luo Y, Song Q, Chen D. Clinical and epidemiological features of 36 children with coronavirus disease 2019 (COVID-19) in Zhejiang, China: an observational cohort study. Lancet Infect Dis 2020; 20 (6): 689-96.

33. Götzinger F, Santiago-García B, Noguera -Julián A, Lanaspa M, Lancella L, Calò Carducci $\mathrm{Fl}$, et al. COVID-19 in children and adolescents in Europe: a multinational, multicentre cohort study. The Lancet Child \& Adolescent Health 2020; 10.1016/S2352-4642(20)30177-2. Dosegljivo na: https://www.thelancet.com/action/ showPdf?pii=S2352-4642\%2820\%2930177-2.

34. Garazzino S, Montagnani C, Dona D, Meini A, Felici E, Vergine G. Multicenter Italian study of SARS-CoV-2 infection in children and adolescents, preliminary data as at 10 April 2020. Euro Surveill 2020; 25 (18): 2000600.

35. Bialek S, Gierke R, Hughes M, McNamara LA, Pilishvili T, Skoff T. Coronavirus Disease 2019 in Children - United States, February 12 - April 2, 2020. MMRW Morb Mortal Wkly Rep 2020; 69 (14): 422-6.

36. Rodriguez-Morales AJ, Cardona-Ospina JA, Gutierrez-Ocampo E, Villamizar-Peña $R$, Holguin-Rivera Y, Escalera-Antezana JP, et al. Clinical, laboratory and imaging features of COVID-19: A systematic review and meta-analysis. Travel Med Infect Dis 2020; 13: 101623.

37. Andina D, Noguera-Morel L, Bascuas-Arribas M, Gaitero-Tristan J, Alonso-Cadenas JA, et al. Chilblains in children in the setting of COVID-19 pandemic. Pediatr Dermatol 2020; 10.1111/ pde.14215.

38. Wang Y, Lui Y, Liu L, Wang $X$, Luo N, Li L. Clinical outcome of 55 asymptomatic cases at the time of hospital admission infected with SARS-Coronavirus-2 in Shenzhen, China. J Infect Dis 2020; 221 (11): 1770-4.

39. Dong $Y$, Mo X, Hu Y, Qi X, Jiang F, Tong S. Epidemiological Characteristics of 2143 Pediatric Patients With 2019 Coronavirus Disease in China.
Pediatrics 2020; 145 (6): e20200702.

40. Shekerdemian LS, Mahmood NR, Wolfe KK, Riggs BJ, Ross CE et al. Characteristics and Outcomes of Children With Coronavirus Disease 20019 (COVID-19) Infection Admitted to US and Canadian pediatric Intensive Care Units. JAMA Pediatr 2020 [Epub ahead of print]. Dosegljivo na: https://jamanetwork.com/journals/ jamapediatrics/fullarticle/2766037.

41. Turner $D$, Huang $Y$, Martín-de-Carpi J, Aloi M, Focht G, Kang B, et al. COVID-19 and Paediatric Inflammatory Bowel Diseses: Global Experience and Provisional Guidance (March 2020) from the Paediatric IBD Porto group of ESPGHAN. J Pediatr Gastroenterol Nutr 2020 [Epub ahead of print]. Dosegljivo na: https:// penta-id.org/wp/wp-content/uploads/2020/04/ COVID_19_and_Paediatric_Inflammatory_Bowel.96116.pdf.

42. Balduzzi A, Brivio E, Rovelli A, Rizzari C, Gasperini $S$, Melzi ML et al. Lessons after the early management of the COVID-19 outbreak in a pediatric transplant and hemato-oncology center embedded with a COVID-19 dedicated hospital in Lombardia, Italy. Estoteparati. Bone Marrow Transplant 2020; 20 (4): 1-6.

43. ERS COVID-19 paediatric cases - survey. Preliminarno poročilo - osebna dokumentacija Krivec $\mathrm{U}$.

44. Shen $K$, Yang $Y$, Wang $T$, Zhao D, Jiang $Y$, Jin $R$, et al. Diagnosis, treatment, and prevention of 2019 novel coronavirus infection in children, experts' consensus statement. World J Pediatr 2020; (2): 1-9. Dosegljivo na: https://www.ncbi. nlm.nih.gov/pmc/articles/PMC7090771/.

45. Royal College of Paediatrics and Child Health. Guidance: Paediatric multisystem inflammatory syndrome temporally associated with COVID-19. Dosegljivo na: https://www.rcpch. ac.uk/sites/default/files/2020-05/COVID-19-Paediatric-multisystem-\%20inflammatory\%20syndrome-20200501.pdf.

46. European Centre for Disease Prevention and Control. Paediatric inflammatory multisystem syndrome and SARS-CoV-2 infection in children - 15 May 2020. Stockholm: ECDC; 2020.

Dosegljivo na: https://www.ecdc.europa.eu/en/ publications-data/paediatric-inflammatory-multisystem-syndrome-and-sars-cov-2-rapid-risk-assessment\#no-link.

47. World Health Organisation. Multisystem inflammatory syndrome in children and adolescents temporally related to COVID-19. Dosegljivo na: https://www.who.int/news-room/ commentaries/detail.

48. Cheng MH, Zhang S, Porritt RA, Arditi M, Bahar I. An insertion unique to SARS-CoV-2 exhibits superantigenic character strengthened by recent mutations. Biorxiv [Preprint] 2020. Dosegljivo na: https://www.biorxiv.org/content/1 0.1101/2020.05.21.109272v1

49. Henry BM, Lippi G, Plebani M. Laboratory abnormalities in children with novel coronavirus disease 2019. Clin Chem Lab Med 2020; cclm2020-0272. Dosegljivo na: https://www.degruyter.com/view/journals/cclm/ahead-of-print/ article-10.1515-cclm-2020-0272/article-10.1515cclm-2020-0272.xml.

50. Sethurman $N$, Jeremiah SS, Ryo A. Interpreting diagnostic tests for SARS-CoV-2. JAMA
2020; 10.1001/jama.2020.8259. Dosegljivo na: https://jamanetwork.com/journals/jama/ fullarticle/2765837.

51. Wolfel R, Corman VM, Guggems W, Seilmaier $\mathrm{M}$, Zange $\mathrm{S}$, Muller MA, et al. Virological assessment of hospitalized patients with COVID-2019. Nature 2020; 581,465-9.

52. Chalmers V. South Korea admits 292 coronavirus 'reinfections' were false positives as officials warn fragments of the virus can linger in the body for months. Mail Online, 30. april 2020. Dosegljivo na: https://www. dailymail.co.uk/news/ article-8273947/South-Korea-admits-292-coronavirus-reinfections-false-positives.html.

53. Cheng $H$, Jian SW, Liu DP, Ng T, Huang WT, Lin HH. Contact tracing assessment of COVID-19 transmission dynamics in Taiwan and risk at different exposure periods before and after symptom onset. JAMA Intern Med 2020; 10.1001/jamainternmed.2020.2020. Dosegljivo na: https://jamanetwork.com/journals/ jamainternalmedicine/fullarticle/2765641.

54. Wang W, Xu Y, Gao R, Lu R Han K, et al. Detection of SARS-Cov-2" in different types of clinical speciments. Jama; 323 (18): 1843-4.

55. Xiang F, Wang $X$, He X, Peng Z, Yang B, Zhang J, et al. Antibody Detection and Dynamic Characteristics in Patients with COVID-19. Clin Infect Dis 2020; ciaa461. Dosegljivo na: https://www.ncbi.nlm.nih.gov/pmc/articles/ PMC 7188146/.

56. Chiotos K, Hayes M, Kimberlin DW, Jones SB, James SH, Pinninti SG. Multicenter Initial Guidance on Use of Antivirals for Children With Coronavirus Disease 2019/Severe Acute Respiratory Syndrome Coronavirus 2. Jour Ped Infect Dis Soc 2020; piaa045. Dosegljivo na: https://www. ncbi.nlm.nih.gov/pmc/articles/PMC 7188128/.

57. McCreary EK, Pogue JM. COVID-19 Treatment: A Review of Early and Emerging Options. Open Forum Infect Dis 2020; 7 (4): ofaa105. Dosegljivo na: https://www.ncbi.nlm.nih.gov/ pmc/articles/PMC7144823/.

58. Jean S-S, Leec P-I, Hsueh P-R. Treatment options for COVID-19: The reality and challenges. Journal of Microbiology, Immunology and Infection 2020 [Preprint]. Dosegljivo na: https:// www.sciencedirect.com/science/article/pii/ S1684118220300943.

59. Beigel JH, Tomashek KM, Dodd LE, Mehta $A K$, Zingman BS, Kalil AC, et al. Remdesivir for the Treatment of Covid-19 - Preliminary Report. N Engl J Med 2020; oa2007764. Dosegljivo na: https://www.nejm.org/doi/full/10.1056/ NEJMoa2007764.

60. Cao B, Wang Y, Wen D, Liu W, Wang J, Fan $G$, et al. A Trial of Lopinavir-Ritonavir in Adults Hospitalized with Severe Covid-19. N Engl J Med 2020; 382: 1787-99.

61. Wang M, Cao R., Zhang L, Yang $X$, Liu J, Xu $M$, et al. Remdesivir and chloroquine effectively inhibit the recently emerged novel coronavirus (2019-nCoV) in vitro. Cell Res 2020; 30: 269-71. 62. Horby P, Lim WS, Emberson J, Mafham M, Bell J, Linsell $L$, et al. Effect of Dexamethasone in Hospitalized Patients with COVID-19: Preliminary Report. Infectious Diseases (except HIV/AIDS) 2020 [Internet]. Dosegljivo na: http://medrxiv. org/lookup/doi/10.1101/2020.06.22.20137273. 
63. Chen L, Xiong J, Bao L, Shi Y. Convalescent plasma as a potential therapy for COVID-19. Lancet Infect Dis 2020; 20 (4): 398-400.

64. Chen WH, Strych U, Hotez PJ, Bottazzi ME. The SARS-CoV-2 vaccine pipeline: an overview. Curr Trop Med Rep 2020; 3: 1-4.

65. Dhama K, Sharun K, Tiwari R, Dadar M, Malik YS, Singh KP, Chaicumpa W. COVID-19, an emerging coronavirus infection: advances and prospects in designing and developing vaccines, immunotherapeutics, and therapeutics. Hum Vaccin Immunother 2020; 18:1-7.

66. World Health Organisation. DRAFT landscape of COVID-19 candidate vaccines. Dosegljivo na: https://www.who.int/who-documents-detail/ draft-landscape-of-covid-19-candidate-vaccines

67. World Health Organisation. Infection prevention and control during health care when novel coronavirus (nCoV) infection is suspected. Dosegljivo na: https://www.who.int/publications-detail/infection-prevention-and-control-during-health-care-when-novel-coronavirus-(ncov)-infection-is-suspected-20200125.

68. European Centre for Disease Prevention and Control. Guidance for health system contingency planning during widespread transmission of SARS-COV-2 with high impact on healthcare services. Stockholm: ECDC; 2020. Dosegljivo na: https://www.ecdc.europa.eu/sites/default/ files/documents/COVID-19-guidance-health-systems-contingency-planning.pdf.

69. European Centre for Disease Prevention and Control. Infection prevention and control for COVID-19 in healthcare settings - Third update. Stockholm: ECDC; 2020. Dosegljivo na: https:// www.ecdc.europa.eu/en/publications-data/ infection-prevention-and-control-and-preparedness-covid-19-healthcare-settings.

70. Chin AWH, Chu JTS, Perera MRA, Hui KPY, Yen $\mathrm{H}-\mathrm{L}$, Chan MCW, et al. Stability of SARS-CoV-2 in different environmental conditions. Lancet Microbe 2020; S2666-5247(20)30003-3. Dosegljivo na: https://www.thelancet.com/journals/lanmic/article/PIIS2666-5247(20)30003-3/ fulltext.

71. Lazzerini M, Barbi E, Apicella A, Marchetti F, Cardinale F, Trobia G. Delayed access or provision of care in Italy resulting from fear of COVID-19. The Lancet Child \& Adolescent Health 2020; 4 (5): e10-1. dr. Tina Plankar Srovin, dr. med.

(Kontaktna oseba / Contact person) Klinika za infekcijske bolezni in vročinska stanja Ljubljana, Univerzitetni klinični center Ljubljana, Japljeva 2, Ljubljana, Slovenija

Tanja Avramoska, dr. med.

Klinika za infekcijske bolezni in vročinska stanja Ljubljana, Univerzitetni klinični center Ljubljana, Japljeva 2, Ljubljana, Slovenija

Natalija Bahovec, dr. med.

Klinika za infekcijske bolezni in vročinska stanja Ljubljana, Univerzitetni klinični center Ljubljana, Japljeva 2, Ljubljana, Slovenija

Simona Bizjak Vojinovič, dr. med. Klinika za infekcijske bolezni in vročinska stanja Ljubljana, Univerzitetni klinični center Ljubljana, Japljeva 2, Ljubljana, Slovenija

Aida Granda, dr. med.

Klinika za infekcijske bolezni in vročinska stanja Ljubljana, Univerzitetni klinični center Ljubljana, Japljeva 2, Ljubljana, Slovenija

asist. Liza Lea Lah, dr. med.

Klinika za infekcijske bolezni in vročinska stanja Ljubljana, Univerzitetni klinični center Ljubljana, Japljeva 2, Ljubljana, Slovenija

asist. Tatjana Mrvič, dr. med.

Klinika za infekcijske bolezni in vročinska stanja Ljubljana, Univerzitetni klinični center Ljubljana, Japljeva 2, Ljubljana, Slovenija

Veronika Osterman, dr. med.

Klinika za infekcijske bolezni in vročinska stanja Ljubljana, Univerzitetni klinični center Ljubljana, Japljeva 2, Ljubljana, Slovenija

Petra Prunk, dr. med.

Klinika za infekcijske bolezni in vročinska stanja Ljubljana, Univerzitetni klinični center Ljubljana, Japljeva 2, Ljubljana, Slovenija asist. dr. Mojca Rožič, dr. med.

Klinika za infekcijske bolezni in vročinska stanja Ljubljana, Univerzitetni klinični center Ljubljana, Japljeva 2, Ljubljana, Slovenija

Urška Šivic, dr. med.

Klinika za infekcijske bolezni in vročinska stanja Ljubljana, Univerzitetni klinični center Ljubljana, Japljeva 2, Ljubljana, Slovenija

Katarina Vincek, dr. med.

Klinika za infekcijske bolezni in vročinska stanja Ljubljana, Univerzitetni klinični center Ljubljana, Japljeva 2, Ljubljana, Slovenija

prim. mag. Breda Zakotnik, dr. med. Klinika za infekcijske bolezni in vročinska stanja Ljubljana, Univerzitetni klinični center Ljubljana, Japljeva 2, Ljubljana, Slovenija 